\title{
GONAF - the borehole Geophysical Observatory at the North Anatolian Fault in the eastern Sea of Marmara
}

\author{
Marco Bohnhoff ${ }^{1,2}$, Georg Dresen ${ }^{1}$, Ulubey Ceken ${ }^{3}$, Filiz Tuba Kadirioglu ${ }^{3}$, Recai Feyiz Kartal ${ }^{3}$, \\ Tugbay Kilic ${ }^{3}$, Murat Nurlu ${ }^{3}$, Kenan Yanik ${ }^{3}$, Digdem Acarel ${ }^{1}$, Fatih Bulut ${ }^{1}$, Hisao Ito ${ }^{4}$, Wade Johnson ${ }^{5}$, \\ Peter Eric Malin ${ }^{1}$, and Dave Mencin ${ }^{5}$ \\ ${ }^{1}$ GFZ German Research Centre for Geosciences, Section 4.2 "Geomechanics and Rheology”, \\ Potsdam, 14473, Germany \\ ${ }^{2}$ Free University Berlin, Department of Earth Sciences, Berlin, 12249, Germany \\ ${ }^{3}$ AFAD Disaster and Emergency Management Presidency, Earthquake Department Ankara, 06510, Turkey \\ ${ }^{4}$ Japan Agency for Marine-Earth Science and Technology (JAMSTEC), Yokohama, 236-0001, Japan \\ ${ }^{5}$ UNAVCO, Boulder, Colorado 80301, USA
}

Correspondence to: Marco Bohnhoff (bohnhoff@gfz-potsdam.de)

Received: 4 November 2016 - Revised: 2 January 2017 - Accepted: 4 January 2017 - Published: 31 May 2017

Abstract. The Marmara section of the North Anatolian Fault Zone (NAFZ) runs under water and is located less than $20 \mathrm{~km}$ from the 15-million-person population center of Istanbul in its eastern portion. Based on historical seismicity data, recurrence times forecast an impending magnitude $M>7$ earthquake for this region. The permanent GONAF (Geophysical Observatory at the North Anatolian Fault) has been installed around this section to help capture the seismic and strain activity preceding, during, and after such an anticipated event.

GONAF (Geophysical Observatory at the North Anatolian Fault) is currently comprised of seven $300 \mathrm{~m}$ deep vertical seismic profiling stations and four collocated $100 \mathrm{~m}$ deep borehole strainmeters. Five of the stations are located on the land surrounding the Princes Islands segment below the eastern Sea of Marmara and two are on the near-fault Princes Islands south of Istanbul. The $300 \mathrm{~m}$ boreholes have 1, 2, and $15 \mathrm{~Hz} 3-\mathrm{C}$ seismometers near their bottoms. Above this are vertical, $1 \mathrm{~Hz}$, seismometers at $\sim 210,140$, and $70 \mathrm{~m}$ depths. The strainmeter boreholes are located within a few meters of the seismometer boreholes and contain horizontal strain tensor sensors and $2 \mathrm{~Hz} 3-\mathrm{C}$ seismometers at their bottoms. This selection of instruments and depths was made so as to ensure high-precision and broad-frequency earthquake monitoring and vertical profiling, all under low-noise conditions.

GONAF is the first ICDP-driven project with a primary focus on long-term monitoring of fault-zone dynamics. It has already contributed to earthquake hazard studies in the Istanbul area in several ways. Combining GONAF recordings with existing regional seismic stations now allows monitoring of the NAFZ offshore of Istanbul down to magni- tudes $M<0$. GONAF also improves the resolution of earthquake hypocenters and source parameters, better defining local fault branches, their seismicity, and earthquake potential. Using its vertical distribution of sensors, it has directly measured depth-dependent seismic side-effects for ground shaking studies. GONAF is starting to address fundamental questions related to earthquake nucleation, rupture dynamics, temporal changes in material properties and strain.

\section{Tectonic context: the Marmara seismic gap}

The continental North Anatolian Fault Zone (NAFZ) spans some $1200 \mathrm{~km}$, from eastern Anatolia to the northern Aegean Sea (e.g., Barka, 1992; Sengör et al., 2005; Bohnhoff et al., 2016a). It forms the plate boundary between the Anatolian plate in the south and the Eurasian plate in the north. It is one of the most active plate-bounding strike-slip faults in the world, slipping at a rate of $20-30 \mathrm{~mm} \mathrm{yr}^{-1}$, with the largest rates at its western end (McClusky et al., 2000; Reilinger et al., 2006). Its kinematic framework is driven by the northward-pushing Arabian plate in the east and the 


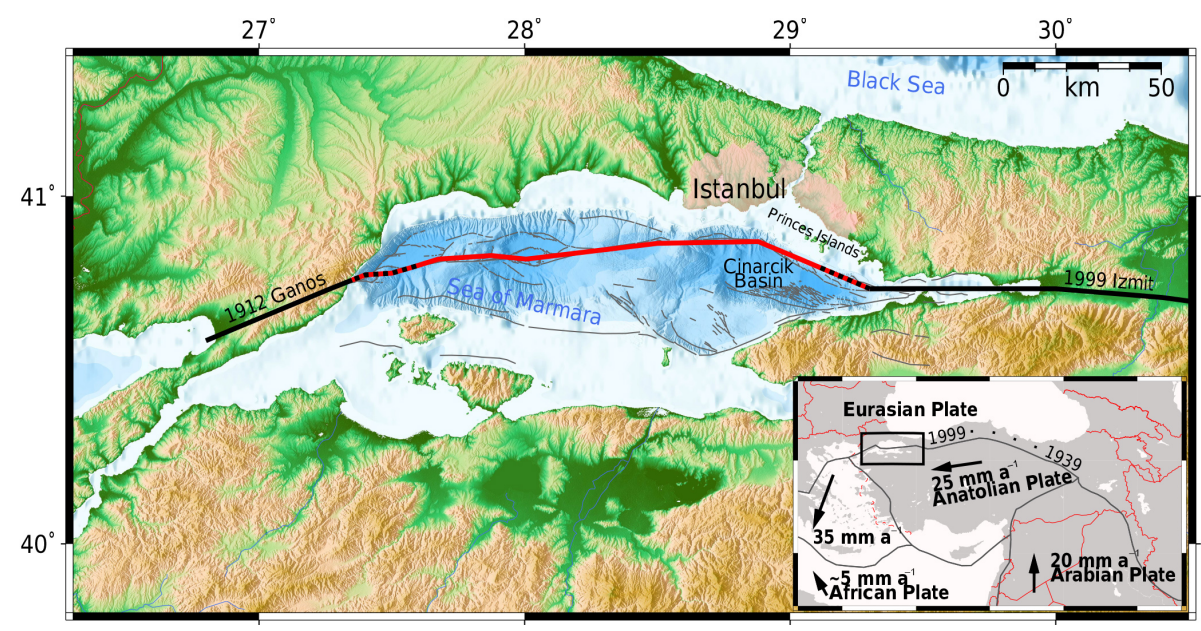

Figure 1. The Marmara region in northwestern Turkey with the main strand of the North Anatolian Fault Zone (NAFZ). The offshore Marmara section (red) is bounded by the two last major ruptures of the region, the 1912 Ganos event to the west and the 1999 Izmit event to the east (both indicated in black). The Marmara section is the last segment of the entire NAFZ that has not been activated since 1766. It hosts the potential of generating an earthquake magnitude $M$ of up to 7.4 in the near future and within a distance of only $20 \mathrm{~km}$ to the Istanbul metropolitan area. The location map on the lower right shows the main tectonic plates and their average GPS-derived horizontal velocity with respect to fixed Eurasia.

southward-pulling rollback of the Hellenic subduction zone in the west, forcing the Anatolian plate to rotate counterclockwise (Flerit et al., 2004; Bohnhoff et al., 2005; Bulut et al., 2012).

In the last century, almost the entire NAFZ ruptured in a series of $M>7$ earthquakes, starting with the 1912 Ganos event west of the Sea of Marmara. The next major event then occurred in Erzincan, eastern Anatolia, in 1939, and was followed by a systematic westward propagation of earthquakes (Stein et al., 1997; Sengör et al., 2005). This sequence ended with the $M 7.4$ İzmit and M7.1 Düzce earthquakes in 1999, just east of the Sea of Marmara (Tibi et al., 2001; Barka et al., 2002; Bohnhoff et al., 2016b).

Currently, the NAFZ section below the Sea of Marmara is the only portion of the entire fault zone that has not failed in a major earthquake since 1766 (Fig. 1). The Marmara section has produced several earthquakes as large as $M \sim 7.4$ in historic times, at an average recurrence time of 200-250 years (Parsons, 2004; Bohnhoff et al., 2016a). It would appear then that it is currently in the final stage of its seismic cycle, with a $35-70 \%$ probability of a $M>7$ earthquake occurring by 2034 (Parsons, 2004; Murru et al., 2016).

Unfortunately, the eastern part of this section - the Princes Islands segment - runs within $20 \mathrm{~km}$ of the $15+$ million inhabitants of the Istanbul metropolitan area. Aside from the potential for a tragic loss of lives, this region also accounts for about $45 \%$ of the national production and about $23 \%$ of the total Turkish gross national product. For these reasons, significant efforts are being made by the Turkish authorities to assess these earthquake hazards and mitigate their risks. Current estimates of damage from an expected $M=7.5$ earthquake below the Sea of Marmara suggest up to
90000 fatalities. Up to 800000 people might be affected and immediate economic losses could be up to USD 40 billion (Bas and Yagci, 2008).

In such a complex natural and urban setting, highresolution seismic monitoring under low-noise conditions is of central relevance. It presents a critical need to conduct research in refining potential rupture scenarios, identifying potential nucleation points, and rupture directivity models for the pending earthquake. In this paper we summarize the objectives and implementation of the GONAF observatory. We also document our achievements in earthquake detection, waveform quality improvement, and detection of strain by using the downhole seismic arrays and strainmeters.

\section{Scientific objectives}

The NAFZ is a right-lateral strike-slip fault. However, the transtensional setting of the broader Marmara region also produces surprisingly large normal faulting events, e.g., a $M_{\mathrm{s}}$ 6.3 earthquake along the Çinarcık segment below the eastern Sea of Marmara in 1963 (Ayhan et al., 1981). There is an ongoing debate on whether the pending Marmara event will be pure strike-slip or might include a normal component with consequent tsunami potential (Yalciner et al., 2002; LePichon et al., 2001; Armijo et al., 1999, 2005). Accordingly, for all the risk factors we have cited, it is a pressing matter to resolve the dominant kinematic setting along the Marmara section. This is especially true for the Princes Islands segment just offshore from Istanbul.

Two equally important objectives are to identify potentially creeping and locked fault patches (asperities) - the 
latter as potential nucleation points for a large rupture with subsequent directivity effects and ground shaking. The installation of seismometer arrays in boreholes allows not only relatively noise-free waveform recordings, but also studies of near-surface ground motion amplification effects. Fault creep observed on borehole strainmeters provides strong constraints on the accumulation of unreleased strain, both in terms of the amount of fault slip and its areal distribution.

The fact that the entire Marmara section of the NAFZ is under water makes high-resolution seismic and geodetic monitoring of its seismicity and potential creep a challenging task. Our first step in this regard was to install the surfacebased PIRES seismic network on the Princes Islands in 2006. The PIRES network has lowered the magnitude of completeness for local microseismicity by 1 order of magnitude to $\sim 1.7$ (Bulut et al., 2009, 2011). Based on a 4-year PIRES seismicity catalog, Bohnhoff et al. (2013) were able to identify $\mathrm{a} \geq 30 \mathrm{~km}$ long aseismic fault patch along the Princes Islands segment extending down to a depth of $10 \mathrm{~km}$. The authors concluded that this segment is currently locked and thus represents a potential nucleation point for the next Marmara event. This view is also supported by Global Positioning Satellite (GPS) data (Ergintav et al., 2014).

Beyond the PIRES network, better monitoring of the eastern Sea of Marmara and the Princes Islands segment would be difficult to achieve with surface instruments due to the area's ubiquitous anthropogenic noise. Moreover, near-fault, subareal locations only exist on the Princes Islands. Given these boundary conditions, the GONAF concept of boreholebased geophysical instrumentation surrounding the eastern Sea of Marmara region was conceived and developed in the context of an International Continental Drilling Program (ICDP) project.

Overall, the goal of the GONAF project is a substantially better characterization of the seismic gap first identified by the PIRES and other associated networks. In the long run, outside of any pending significant earthquake, this objective will allow scientific correlations with the findings of other strike-slip faults, such as the San Andreas fault in California. In addition to the study of brittle failures in the form of seismic events, GONAF is also addressing the role of aseismic deformation processes through strain monitoring. These processes included fault creep and slow earthquakes, which are now recognized as playing equally fundamental roles in the seismomechanics of the earth's crust.

\section{Strategy}

GONAF is a joint research venture between GFZ in Potsdam, Germany, and the AFAD Disaster and Emergency Management Presidency of Turkey, headquartered in Ankara. It is co-funded by GFZ, AFAD, the Turkish Ministry of Development, the International Scientific Drilling Program (ICDP), the German Helmholtz Association (HGF), and the NSF through UNAVCO, a non-profit US university-governed consortium dedicated to supporting geodetic studies. Key aspects of a scientific and technical program for a long-term geophysical observatory for the NAFZ were discussed at an ICDP-funded workshop in Istanbul in 2007 (Dresen et al., 2008). A consensus was reached that the eastern Marmara NAFZ is unique as a segment of a major transform fault, one that is nearing the end of its seismic cycle. It was also considered a worthy technical challenge, in that deep borehole observatories represent the only possibility of obtaining lownoise geophysical data in such a densely populated region.

Following the workshop, an implementation plan was developed that resulted in an ICDP full proposal (Bohnhoff et al., 2010). This was followed by further refinement of the borehole observatory concept, all pointing towards a first ICDP-driven "fault zone seismic monitoring project". Significantly, the initial concept of one or two $2 \mathrm{~km}$ deep instrumented boreholes was modified towards a multiborehole network of several $300 \mathrm{~m}$ deep vertical seismic arrays (Fig. 2). The aim of this revision was that even a $2 \mathrm{~km}$ deep borehole would not have allowed one to measure crustal stresses of sufficient quality due to the influence of the $\sim 1 \mathrm{~km}$ escarpment down to the Cinarcik Basin a few kilometers offshore of the near-fault islands and to allow for homogenous low-detection threshold seismic monitoring throughout the eastern Sea of Marmara following the concept of, e.g., the Parkfield High Resolution Seismic Network (HRSN). Following several years of GONAF downhole seismic monitoring along the Princes Islands segment, the potential for eventually drilling individual deeper drill holes will then be re-evaluated.

The first GONAF borehole station was drilled and completed in 2012 on the Tuzla peninsula in eastern Istanbul (Fig. 2). This site combined good access to a secure location on land and the vicinity of a prominent seismicity cluster (Bulut et al., 2011; Prevedel et al., 2015; Raub et al., 2016; Fig. 3). Further GONAF stations were then implemented during 2013-2015. The current seismic observatory now consists of seven borehole seismic stations. Each station is equipped with a vertically distributed array of seismometers, including a selection of different natural-frequency seismometers at the bottom of the boreholes (Figs. 2 and 4). Two of the GONAF borehole arrays are located on the islands of Sivriada and Büyakada. These two sites are less than $5 \mathrm{~km}$ from the Princes Islands segment of the NAFZ. The remaining four GONAF stations are located on the Armutlu Peninsula south of the Cinarcik Basin (Fig. 2). This network of borehole stations provides a nearly complete azimuthal coverage for microseismicity occurring below the eastern Sea of Marmara.

In addition to the seven $300 \mathrm{~m}$ wells drilled for the seismic arrays, four $100 \mathrm{~m}$ deep boreholes were drilled for the installation of UNAVCO Plate Boundary Observatory instruments. These are collocated with four seismometer array stations: Sivriada, Büyükada, Esenköy, and Bozburun (Fig. 2). 


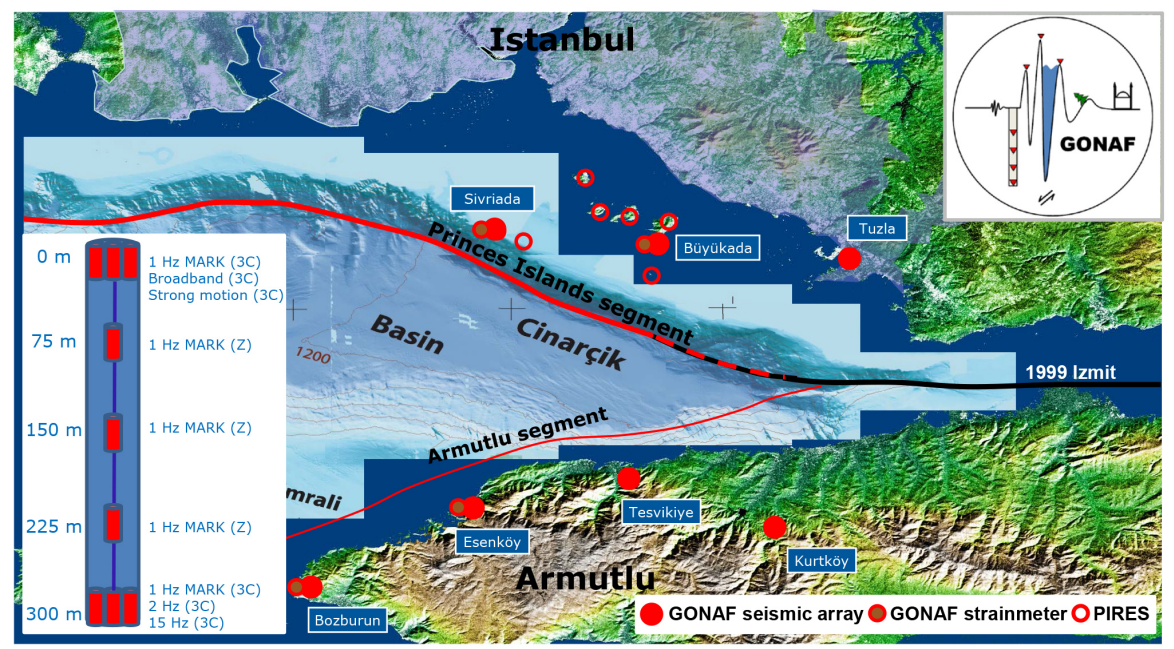

Figure 2. The eastern Marmara region with the Princes Islands segment as the main NAFZ fault trace in this region. Bold red dots indicate locations of the ICDP-GONAF observatory where seismometer arrays were deployed in $300 \mathrm{~m}$ deep boreholes. Brown dots indicate locations with additional $100 \mathrm{~m}$ deep strainmeter wells. The inset on the lower left shows the sensor distribution in the GONAF wells including multiple seismic sensors of different natural frequencies to sample the entire frequency band of the seismic wavefield (see text for details). Open red circles are surface-based stations of the PIRES seismic network on the Princes Islands.

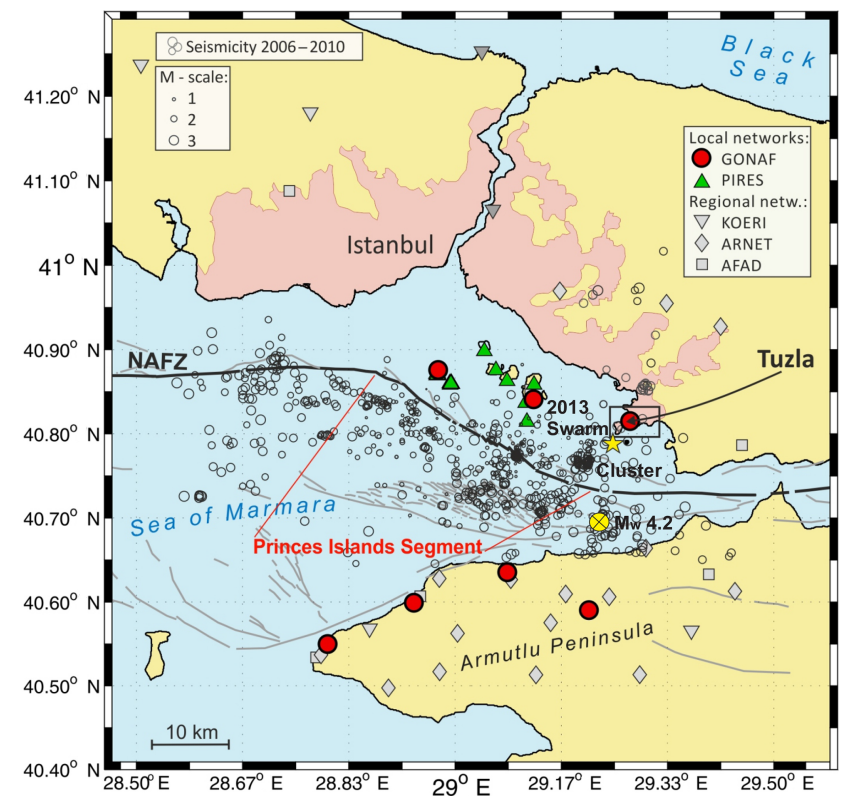

Figure 3. Seismicity map for the eastern Sea of Marmara region for the time period 2006-2010 from surface recordings of the PIRES, AFAD and KOERI stations (Bohnhoff et al., 2013; Prevedel et al., 2015). The yellow star indicates the location of the 2013 microseismic swarm recorded by GONAF-Tuzla seismometers (Prevedel et al., 2015; Raub et al., 2016). The yellow circle indicates the location of the Yalova 25 June $2016 M_{\mathrm{W}} 4.2$ earthquake of which waveforms obtained at the GONAF-Tesvikiy (TESV; see Fig. 2 for location) vertical seismic array are shown in Figs. 5-7.
These instruments were added to the GONAF plan in order to extend its sensitivity to the long-period deformations of fault creep and slow earthquakes, both below the passband of the seismic sensors. The final monitoring concept foresees that each of the GONAF stations will also be equipped with a set of short-period, broadband, and strong motion sensors at the well head (Fig. 2).

\section{Site selection, sensors, installation, and well completion}

Borehole seismic installations have to take into account borehole diameter and tilt, temperature profile, and lithology. Long-term permitting, accessibility, and the availability of electrical power and mobile data transmission infrastructure complete the requirements for a permanent observatory such as GONAF.

In the case of GONAF, with target depths of $300 \mathrm{~m}$ and a regional geothermal gradient of $\sim 30^{\circ} \mathrm{C} \mathrm{km}^{-1}$, temperature was not an issue with respect to long-term functionality of the downhole equipment. Bottom hole temperatures found during logging were around $25^{\circ} \mathrm{C}$, well below the $50^{\circ} \mathrm{C}$ limit beyond which standard operation of the 1 and $2 \mathrm{~Hz}$ sensors could become an issue. Conventionally drilled boreholes are claimed to be vertical, but are commonly found to deviate by as much as $5-15^{\circ}$. Accordingly, the drilling company was contracted to keep all GONAF boreholes within $3^{\circ}$ from the vertical. This deviation was then checked as part of the $\log$ ging program.

To find sites in the study area that could provide a moreor-less uniform detection threshold, approximate locations 

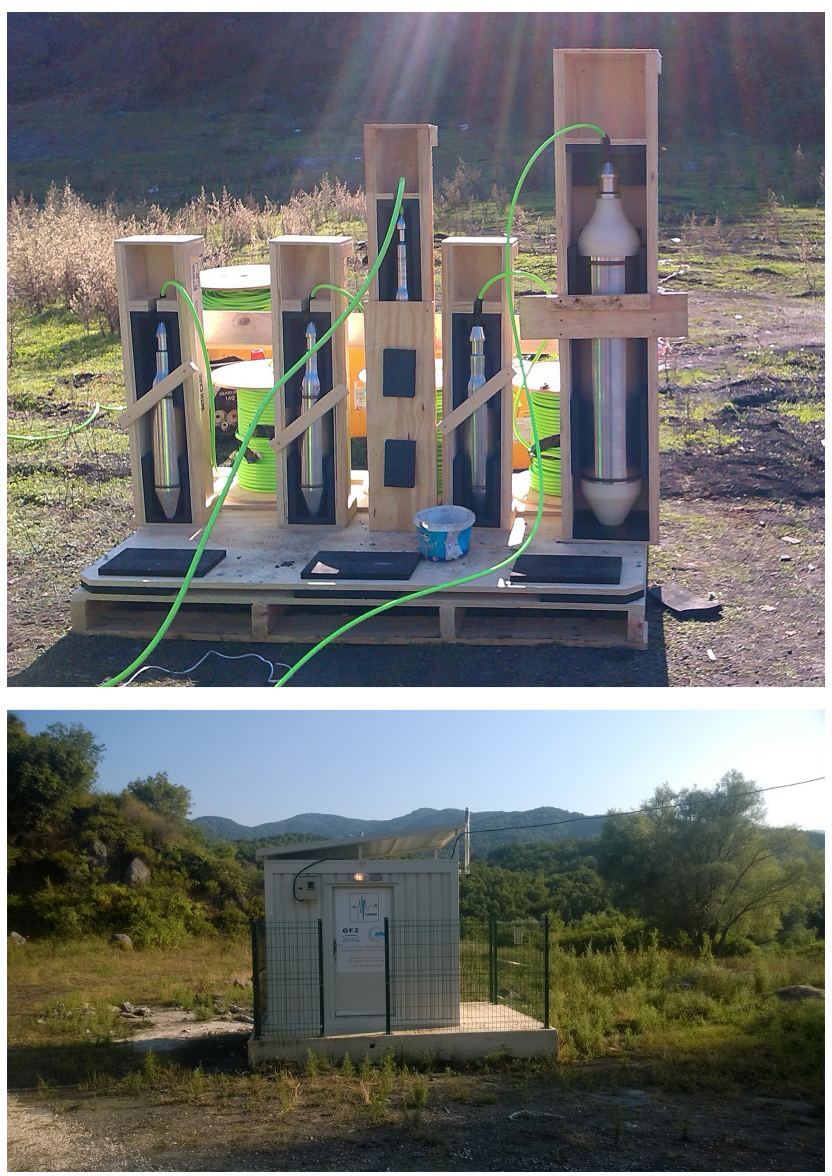

Figure 4. Upper part: GONAF downhole seismic instruments prior to deployment at the Kurtkoy station on the Armutlu Peninsula. The $300 \mathrm{~m}$ deep, gimbaled $1 \mathrm{~Hz} 3-\mathrm{C} \mathrm{L} 4$ seismometer sonde is on the right. In the middle is the combined $300 \mathrm{~m}$ deep $3-\mathrm{C} 15 \mathrm{~Hz}$ DS200 and gimbaled $2 \mathrm{~Hz}$ HS- 1 sonde. The other three sondes are the vertically distributed, gimbaled 1-C $1 \mathrm{~Hz}$ L4 seismometers. For redundancy each sonde has its own waterproof signal cable with an internal Kevlar stress member. Lower part: the $10 \mathrm{ft}$ containers used to cover each station and to house the special low-noise Guralp CMGDM recorders, telemetry systems, and their support equipment.

for GONAF stations were pre-defined on maps. The center pieces of this exercise were the Princes Islands, the only location with short distances to the NAFZ. The island sites on Sivriada and Büyukada were decided upon based on their closest proximity to the target fault section (Fig. 2). The remaining five on-land sites were then optimized after pre-site surveying. For these sites we sought hard-rock conditions to ensure good coupling of the sensors and therefore more faithful recording of the seismic wave field. Permitting issues related to land ownership as well as local electricity and data communication infrastructure were then evaluated.

On the northern shore of the Sea of Marmara, the Tuzla site is located outside the main Istanbul population center but still in an urbanized area. It is the closest station to the Tuzla seismicity cluster (Fig. 3). Along the southern shore of the Sea of Marmara - the northern shore of the Armutlu Peninsula remote spots were easy to find. However, well-consolidated rock conditions were rare. As a result, their locations were determined primarily by sites that seemed to provide the best rock within the spacing and azimuths needed for the overall network.

The seismic sensors deployed in the GONAF borehole are all passive sensors and were selected to cover the entire frequency range intended to be studied. This is primarily defined by the local seismicity that occurs down to the base of the seismogenic layer at $\sim 18 \mathrm{~km}$, resulting in signal frequencies up to a few tens of Hertz (Bohnhoff et al., 2013). However, it is also intended to cover higher frequencies of events occurring near individual wells as well as to detect potentially occurring low-frequency events. All GONAF stations are equipped with a 24-channel Guralp 24-bit data $\log$ ger with variable gain and integrated pre-amplifiers.

The Tuzla station as the first completed GONAF array has three Sercel $1 \mathrm{~Hz} \mathrm{L4}$ vertical component sensors placed at depths of 71, 144, and $215 \mathrm{~m}$, and also Geospace $2 \mathrm{~Hz} \mathrm{HS}$ 1 and $15 \mathrm{~Hz}$ DS2500 three-component sensors at a depth of $288 \mathrm{~m}$. (The L4 sensor were formerly manufactured under the name of Mark Products.) The other six stations with vertically distributed seismic arrays include three vertical $1 \mathrm{~Hz} \mathrm{L4}$ seismometers at nominal $70-75 \mathrm{~m}$ spacing starting at $\sim 70$ $75 \mathrm{~m}$ downhole. At the bottom of each well, at $285-295 \mathrm{~m}$ depths, are 3-C, gimbaled $1 \mathrm{~Hz} \mathrm{L4s,} \mathrm{gimbaled} \mathrm{Geospace} 2 \mathrm{~Hz}$ HS-1s, and fixed Geospace $15 \mathrm{~Hz}$ DS2500s (Figs. 2 and 4). The L4s were selected as they are widely used in local and regional surface seismic networks worldwide, forming something of an international standard. In order to achieve successful installation of them, both a large diameter, internally gimbaled pressure case, and even a larger drill hole were needed. The former requirement is due to the tilt sensitivity of all seismographs with natural frequencies below about $12 \mathrm{~Hz}$. At $1 \mathrm{~Hz}$, even $1^{\circ}$ of tilt effectively removes a horizontal component from scientific analysis due to signal distortion.

To achieve a borehole-tilt tolerance of up to $\sim 8^{\circ}$, a gimbaled case with an outer diameter of $\sim 205 \mathrm{~mm}$ was required. To allow for a comfortable amount of space for this sonde plus a $60 \mathrm{~mm}$ outer diameter (OD) cementing trim tube, a $349 \mathrm{~mm}$ borehole was selected for the borehole inner diameter (ID). With the available space and novelty of placing $1 \mathrm{~Hz}$ sensors at $300 \mathrm{~m}$, it was decided to include the 2 and $15 \mathrm{~Hz}$ units, both for comparison and backup. All sensors were cemented in the boreholes to ensure good coupling and long-term cable stability. The seismic waveform data are currently sampled at $500 \mathrm{~Hz}$ by 18-channel Guralp CMGDM recorders. These recorders are specially equipped with $0.1 \times 10^{-6} \mathrm{~V}$ self-noise pre-amplifiers in order to exceed the self-noise of downhole sensors. The data are then transmitted in real time to GFZ and AFAD headquarters for archiving and analysis. 


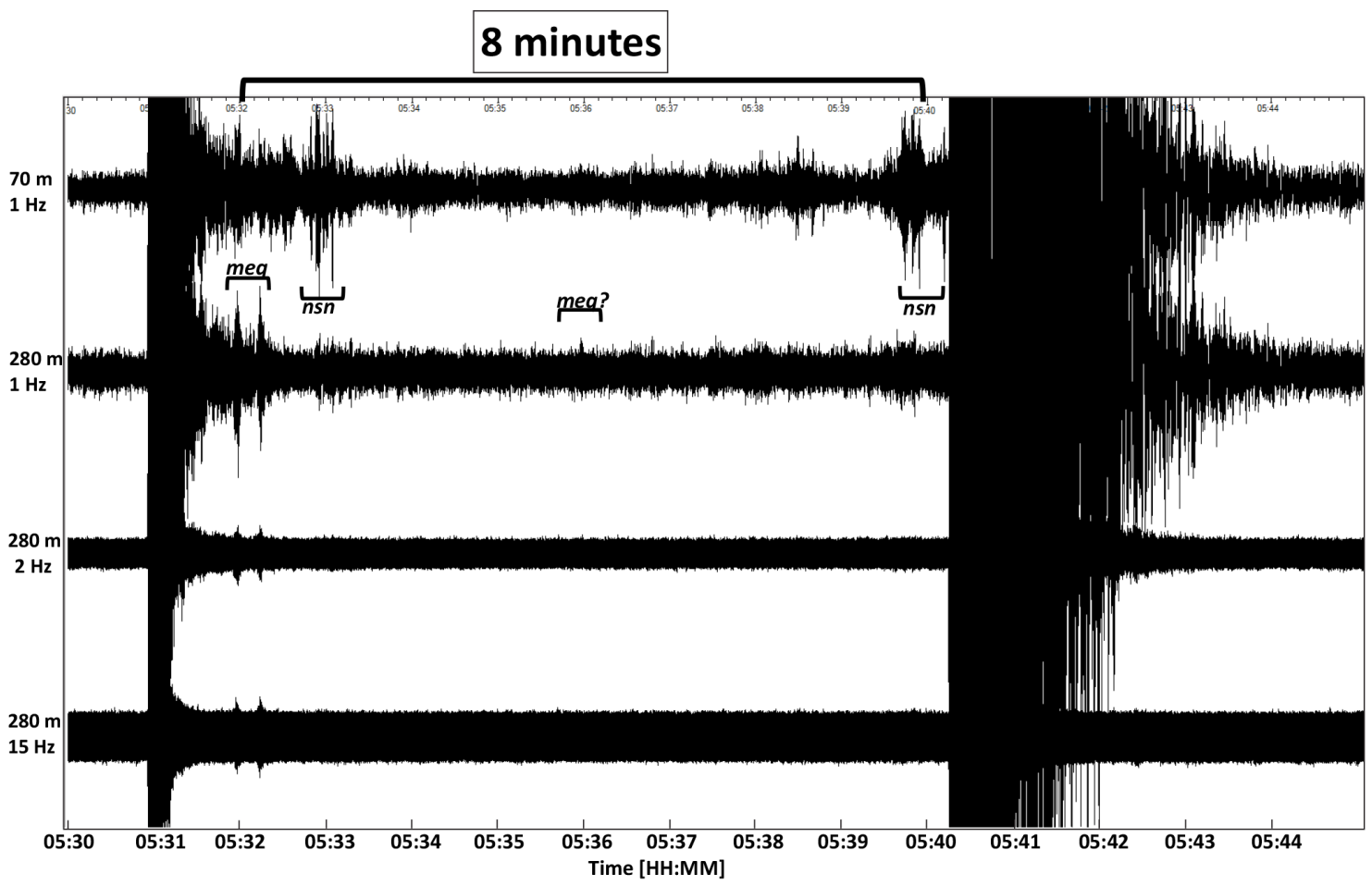

Figure 5. Vertical component seismograms of the Yalova 25 June 2016 foreshock $(\sim 05: 31)$ and $M_{\mathrm{W}} 4.2(\sim 05: 40)$ earthquakes as recorded at the Tesvikiye (TESV) borehole station of the GONAF network. The depth and natural frequency of the TESV sensors are shown on the left. The seismograms were recorded at 500 samples/second and have a usable bandwidth of 0.1 to $200 \mathrm{~Hz}$. The amplitudes of each trace have been normalized to matching maximum values. The times of some near-surface noise (nsn) and smaller earthquakes (meq) are shown with upward and downward facing brackets. These two signals can be easily identified by comparing their signal-to-noise ratios $(\mathrm{S} / \mathrm{Ns})$ as a function of $1 \mathrm{~Hz}$ sensor depth: near-surface noise ratios decrease with depth, while earthquake ratios increase. For example, the microearthquakes that took place just before and above the left end of the $8 \mathrm{~min}$ bar are clearly evident on the $\sim 300$ deep sensor, but are buried in near-surface scattering noise at $\sim 75 \mathrm{~m}$. The $S / N$ for the near-surface noises just after these events is reversed: the large signals at $\sim 75 \mathrm{~m}$ are nearly gone on the $\sim 300 \mathrm{~m}$ sensor. In between the latter times are a number of events with roughly equivalent $S / N \mathrm{~s}(\sim 1)$ at both depths. As is shown in Fig. 6, in many cases it is possible to determine their origin by comparing frequency contents at $\sim 75$ and $\sim 300 \mathrm{~m}$. The 8 min long bracket along the time axis shows the data window used for this analysis in Fig. 6.

All the seismic sensors were tested prior to deployment. Individual sensors were then attached to the $60 \mathrm{~mm}$ cementing trim tube and lowered into the borehole. Once the entire string was lowered into the borehole, the entire well was cemented from the bottom up. Each GONAF station is covered with a $10 \mathrm{ft}$ container to house the 18-channel data logger and its support equipment (Fig. 4).

The four GONAF strainmeter installations were completed after the seismic stations were in place. The main sensors in these installations are GTSM strainmeters, each with three horizontal strain gauges placed at $120^{\circ}$ separations along with a fourth redundant gauge offset $30^{\circ}$ from the principal axis (Gladwin, 1984; Gladwin and Hart, 1985). A 3-C Geospace $2 \mathrm{~Hz}$ HS-1 seismometer is included as a standard part of these systems. Their $100 \mathrm{~m}$ deep wells were first logged to find the most competent rock sections. Then, using the same installation methods as developed for the US Plate Boundary Observatory, the sensors were lowered into a pre-loaded slug of expansive grout at the selected depth.

\section{Technical and first scientific achievements}

The scientific goals set for GONAF required successful completion of its promised improvements in event detection and waveform quality - all dependent on the technical aspects of the still-emerging field of borehole seismology for earthquake research. The first indication that these goals were likely to be met came from the Tuzla site (e.g., Prevedel et al., 2015). This site detected, along with the existing regional surface network, an $M \sim 1.6$ event immediately to its south. Using this event as a correlation template, the Tuzla data in the days surrounding this event were checked for additional weaker events missed by the surface stations. A total of 114 additional events from the same location were identified in the Tuzla GONAF downhole data by these means, all with relative coda magnitudes less than $M \sim 1.6$. The smallest of these events was found to be about $M \sim-1$. Subsequently, at the Tesvikiye GONAF station on the southern Sea of Marmara shore, a pair of events, one with $M \sim 0$ 


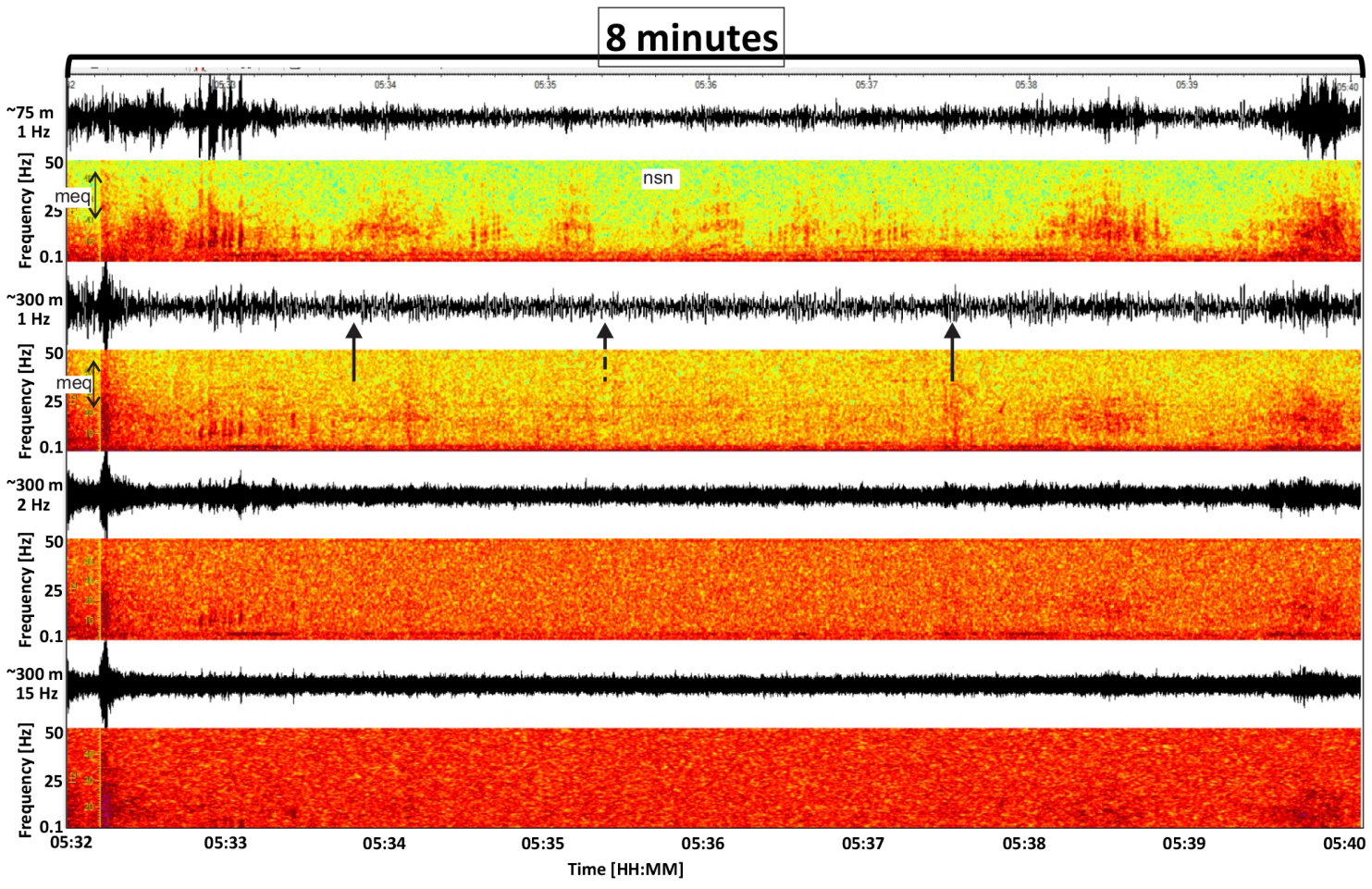

Figure 6. Seismograms and spectrograms illustrating the increasing attenuation of near-surface noise with depth and the increasing microearthquake signals with depth. The depth and natural frequency of the vertical component sensors used to record these motions are shown on the left. The data window is for the 8 min between the main foreshock and the $M_{\mathrm{w}} 4.2$ Yelova earthquake, as shown in Fig. 5 . The 500 samples / second seismograms have been band pass filtered between 0.1 and $50 \mathrm{~Hz}$, and normalized to matching maximum values. The spectrogram bandwidths shown are also between 0.1 and $50 \mathrm{~Hz}$, and their color scales were adjusted to matching maximum values and ranges. Examples of the difference between downgoing near-surface noise ( $n s n)$ and upcoming microearthquake signal (meq) attenuation are labeled. For example, the near-surface noise recorded during the lower time bar on the $\sim 75 \mathrm{~m}$ deep $1 \mathrm{~Hz}$ vertical is nearly absent on the $\sim 300 \mathrm{~m}$ deep sensors; likewise for the signals on either side at the time of 05:33:00. In contrast, the high-frequency microearthquake signal at the beginning of the record on the $\sim 300 \mathrm{~m} 1 \mathrm{~Hz}$ is similarly reduced on the $\sim 75 \mathrm{~m}$ deep sensor. Potential smaller microearthquakes not evident on the $\sim 75 \mathrm{~m}$ deep recording are indicated by black arrows on the $\sim 300 \mathrm{~m} 1 \mathrm{~Hz}$ spectrogram, and are at the detection limit of the GONAF stations. The self-noise floor and sensitivity of the $1 \mathrm{~Hz}$ sensor are clearly evident in these plots: the higher-frequency sensors pick up the first microearthquake event, but the other events are buried by their overall system-response characteristics.

and the other with $M \sim-1$, were also recorded. Except for their amplitudes and signal-to-noise ratios, the initial half seconds of the waveforms of these two events are nearly identical (Prevedel et al., 2015). Judging from their S-P time of $\sim 0.3 \mathrm{~s}$, these events occurred roughly $2.5 \mathrm{~km}$ away. So, based on the smaller event's signal-to-noise ratio of $\sim 10$, it would appear that the detection limit of the $300 \mathrm{~m}$ deep $1 \mathrm{~Hz}$ sensors approaches a relative magnitude $M \sim-1.3$ to -1.4 event at this distance.

The occurrence of a $M_{\mathrm{w}} 4.2$ (AFAD Earthquake Department) event several kilometers northeast of the Tesvikiye GONAF station on 25 June 2016 also helped establish several GONAF seismic station technical achievements, including (1) the improved detection threshold of the $\sim 300 \mathrm{~m}$ deep sensors, (2) the near-surface noise discrimination value of the vertical array, and (3) the relative performance of the three different natural frequency sensors, 1,2 , and $15 \mathrm{~Hz}$ (Figs. 5, 6, and 7).
None of the Tesvikiye sensors appears to have clipped during either the foreshock or main event, which were roughly $15 \mathrm{~km}$ away based on their S-P times of $\sim 2 \mathrm{~s}$. The relative sizes of the aftershock events show that the detection threshold for earthquakes at this distance from this station is around $M \sim 0$. This suggests that the combined detection, location, and unclipped dynamic range of the seven-station network will be at least between $M \sim 0$ and 4.5 or so. By comparing signals and signal-to-noise ratios between the near-surface and deep sensors, the task of separating microearthquakes from cultural noises is greatly facilitated, as demonstrated by the waveform examples shown in Figs. 5 and 7.

Comparison of the codas of the foreshock and the $M_{\mathrm{w}} 4.2$ event as recorded on the three different frequency sensors at $\sim 300 \mathrm{~m}$ shows the well-known apparent "reverse dispersion" of scattered seismic waves: the higher frequencies of the coda cut off earlier than lower ones. The relative signalto-noise ratios between these sensors accords mainly with 


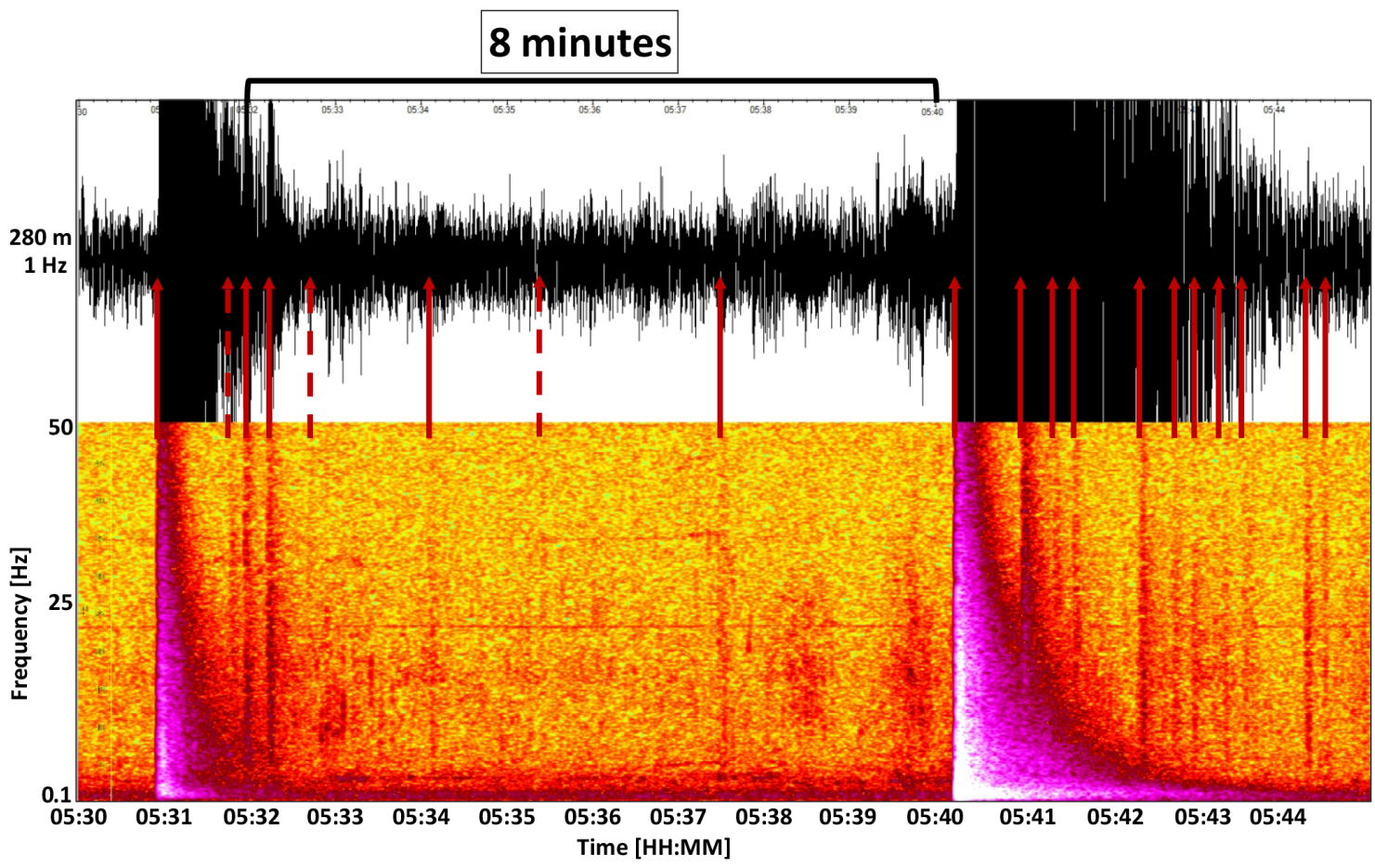

Figure 7. This figure shows the times of earthquakes identified at the $\sim 300 \mathrm{~m}$ deep $1 \mathrm{~Hz}$ GONAF-TESV sensor by their spectra in the $15 \mathrm{~min}$ interval from 05:00:00 to 05:15:00 on 25 June 2016. The solid arrows indicate events with S-P time within 0.1 s of the fore- and main-shocks, the latter arriving at 05:30:56 and 05:40:15. The dashed arrows are events that do not have this S-P time or could not be confidently identified and measured in the waveform data themselves.

their generator constants. Because of its size and consequent combination of coil and magnetic proof mass, the $1 \mathrm{~Hz}$ sensor puts out several times the voltage for equivalent motion as the other two sensors. Hence this sensor overcomes many of the electrical interferences generated by the signal cable and recorder. Ordinarily one would hence select this type of sensor, until one recalls the size of the internally gimbaled sonde and drill hole needed to successfully install them.

Several earthquake research studies have been performed with data from the PIRES and more recently also from the GONAF stations over the last few years. One study focused on using the improved detection limit of these stations to study the microseismic activity along the Princes Islands segment (Bohnhoff et al., 2013). Consistent with previous studies, but now with a much more definitive result, the conclusion is that this crucial portion of the Marmara seismic gap is indeed locked. This view has also been confirmed by GPS data (Ergintav et al., 2014). Therefore, the need to consider it as a potential nucleation point of the pending $M>7$ earthquake has been further substantiated due to better network resolution (Raub et al., 2016). Data from the Tuzla GONAF site have allowed determination of the near-surface structure around the borehole, a key prerequisite for local seismic hazard and risk assessment (Raub et al., 2016). These studies are being extended to all other GONAF sites.
As shown in Fig. 7, the downhole data from the 25 June, 2016, $M_{\mathrm{w}} 4.2$ event have revealed microearthquakes - potentially triggered aftershocks - hidden in the coda of the nearsurface Tesvikiye sensor. As this also appears true for the observed foreshock, all the GONAF seismic data are currently being examined for the time interval surrounding the $M_{\mathrm{w}} 4.2$ mainshock.

\section{Conclusions}

The recently implemented Geophysical Observatory at the North Anatolian Fault (GONAF) in northwestern Turkey aims at monitoring the eastern portion of the NAFZ below the Sea of Marmara. This section of the North Anatolian Fault is currently overdue for a $M>7$ earthquake and runs underwater at less than $20 \mathrm{~km}$ from the 15 -million-person population center of Istanbul. GONAF provides low-noise recordings covering the entire frequency band of signals generated by seismic and creeping processes.

The GONAF observatory currently comprises seven $300 \mathrm{~m}$ deep vertical seismic profiling stations and four collocated $100 \mathrm{~m}$ deep borehole strainmeters. Five of the stations are located on the land surrounding the Princes Islands segment below the eastern Sea of Marmara; two are on the near-fault Princes Islands south of Istanbul. The $300 \mathrm{~m}$ boreholes have 1,2 , and $15 \mathrm{~Hz} 3-\mathrm{C}$ seismometers near their bottoms. Above 
this are vertical, $1 \mathrm{~Hz}$, seismometers at $\sim 210,140$, and $70 \mathrm{~m}$ depths. The strainmeter boreholes are located within a few meters of the seismometers and contain horizontal strain tensor sensors and $2 \mathrm{~Hz} 3-\mathrm{C}$ seismometers at their bottoms.

GONAF is the first ICDP-driven project with a primary focus on long-term monitoring of fault-zone dynamics. It has already contributed to earthquake hazard studies in the Istanbul area in several ways. Combining GONAF recordings with existing regional seismic stations now allows monitoring of the NAFZ offshore of Istanbul down to magnitudes $M<0$. This has improved the resolution of earthquake hypocenters and source parameters, better defining local fault branches, their seismicity, and earthquake potential along the Princes Islands fault segment. Thus, GONAF contributes to addressing fundamental questions related to earthquake nucleation, rupture dynamics, temporal changes in material properties and strain along active transform faults.

\section{Data availability}

Seismic waveform data from the GONAF project will be made available with a 3-year retention period. Strainmeter data are available in real-time through UNAVCO. The waveform recordings shown in Figs. 5-7 are freely available.

Competing interests. The authors declare that they have no conflict of interest.

Acknowledgements. We thank GFZ Potsdam, AFAD Turkey, the Turkish Ministry of Development, the International Scientific Drilling Program (ICDP), the German Helmholtz Association (HGF), and NSF/UNAVCO for funding of the GONAF observatory. We are thankful for logistical support from the AFAD branches and offices in Yalova and İstanbul and acknowledge the hard work performed by the drillers from Bütün Ltd. and G\&M Engineering Ltd. We thank Mustafa Aktar and Haluk Eyidogan for their engagement during the initial phase of the GONAF project. The seismic instrumentation was designed and built at the former Institute of Earth Science and Engineering, University of Auckland, Aotearoa. The ICDP-OSG (Operational Support Group) performed the logging at the Tuzla site. We acknowledge geological interpretation of the well logs by Esen Apart. Christopher Wollin and Christina Raub helped compile Figs. 1 and 3.

Edited by: T. Wiersberg

Reviewed by: L. Chiaraluce and S. Roy

\section{References}

AFAD Earthquake catalogue: Prime Ministry, Disaster and Emergency Management Presidency, Earthquake Department, On-line Catalogue, http://www.deprem.gov.tr, 2007-present.
Armijo, R., Meyer, B., Hubert, A., and Barka, A.: Westward propagation of the North Anatolian fault into the northern Aegean: Timing and kinematics, Geology, 27, 267-270, 1999.

Armijo, R., Pondard, N., Meyer, B., Uçarkus, G., de Lépinay, B. M., Malavieille, J., Dominguez, J., Gustcher, M.-A., Schmidt, S., Beck, C., Çagatay, N., Çakir, Z., Imren, C., Eris, K., Natalin, B., Özalaybey, S., Tolun, L., Lefèvre, I., Seeber, L., Gasperini, L., Rangin, C., Emre, O., and Sarikavak, K.: Submarine fault scarps in the Sea of Marmara pull-apart (North Anatolian fault): Implications for seismic hazard in Istanbul, Geochem. Geophy. Geosy., 6, 1-29, doi:10.1029/2004GC000896, 2005.

Ayhan, E., Alsan, E., Sancaklı, N., and Üçer, S. B.: Turkey and Surrounding Earthquake Catalogue 1881-1980, Boğaziçi University Publications, 1981.

Barka, A. A.: The North Anatolian fault zone, Annales Tectonicae, Spec. Iss. VI, 164-195, 1992.

Barka, A. A., Akyüz, H., Altunel, E., Sunal, G., Cakir, Z., Dikbas, A., Yerli, B., Armijo, R., Meyer, B., de Chabalier, J., Rockwell, T., Dolan, J., Hartleb, R., Dawson, T., Christofferson, S., Tucker, A., Fumal, T., Langridge, R., Stenner, H., Lettis, W., Bachhuber, J., and Page, W.: The Surface Rupture and Slip Distribution of the 17 August 1999 Izmit Earthquake (M7.4), North Anatolian Fault, B. Seismol. Soc. Am., 92, 43-60, 2002.

Bas, M. and Yagci, M. Ö.: Disaster Prevention Mitigation Studies for a Safer Urban Life. Measures for Preventing Disaster of Istanbul Metropolitan Municipality, in: Istanbul Megacity Project Report, Municipality Disaster Management Center (AKOM), edited by: Erdik, M. and Zschau, J., Istanbul, Turkey, 22 October, 2008.

Bohnhoff, M., Harjes, H.-P., and Meier, T.: Deformation and stress regimes in the Hellenic subduction zone from focal Mechanisms, J. Seismol., 9, 341-366, 2005.

Bohnhoff, M., Dresen, G., Aktar, M., Bulut, F., Eyidogan, H., and Ito, H.: GONAF: A deep Geophysical Observatory, Full Proposal to the International Continental Scientific Drilling Program (ICDP), 2010.

Bohnhoff, M., Bulut, F., Dresen, G., Malin, P. E., Eken, T., and Aktar, M.: An earthquake gap south of Istanbul, Nature Commun., 4, 1999, doi:10.1038/ncomms2999, 2013.

Bohnhoff, M., Martínez-Garzón, P., Bulut, F., Stierle, E., and BenZion, Y.: Maximum earthquake magnitudes along different sections of the North Anatolian fault zone, Tectonophysics, 674, 147-165, doi:10.1016/j.tecto.2016.02.028, 2016a.

Bohnhoff, M., Ickrath, M., and Dresen, G.: Seismicity distribution in conjunction with spatiotemporal variations of coseismic slip and postseismic creep along the combined 1999 Izmit-Düzce rupture, Tectonophysics, 686, 132-145, doi:10.1016/j.tecto.2016.07.029, 2016b.

Bulut, F., Bohnhoff, M., Ellsworth, W. L., Aktar, M., and Dresen, D.: Microseismicity at the North Anatolian Fault in the Sea of Marmara offshore of Istanbul, NW Turkey, J. Geophys. Res., 114, 1-16, doi:10.1029/2008JB006244, 2009.

Bulut, F., Ellsworth, W. L., Bohnhoff, M., Aktar, M., and Dresen, G.: Spatiotemporal Earthquake Clusters along the North Anatolian Fault Zone Offshore Istanbul, B. Seismol. Soc. Am., 101, 1759-1768, 2011.

Bulut, F., Bohnhoff, M., Eken, T., Janssen, C., Kilic, T., and Dresen, G.: The East Anatolian Fault Zone: Seismotectonic setting and spatiotemporal characteristics of seismicity based on 
precise earthquake locations, J. Geophys. Res., 117, B07304, doi:10.1029/2011JB008966, 2012.

Dresen, G., Bohnhoff, M., Aktar, M., and Eyidogan, H.: Drilling the North Anatolian Fault, Sci. Dril., 6, 58-59, doi:10.2204/iodp.sd.6.10.2008, 2008.

Ergintav, S., Reilinger, R. E., Cakmak, R., Floyd, M., Cakir, Z., Dogan, U., King, R. W., McClusky, S., and Ozener, H.: Istanbul's Earthquake Hot Spots: Geodetic Constraints on Strain Accumulation along Faults in the Marmara Seismic Gap, Geophys. Res. Lett., 41, 5783-5788, doi:10.1002/2014GL060985, 2014.

Flerit, F., Armijo, R., King, G., and Meyer, B.: The mechanical interaction between the propagating North Anatolian Fault and the back-arc extension in the Aegean, Earth Planet. Sc. Lett., 224, 347-362, 2004.

Le Pichon, X., Sengör, A. M. C., Demirbag, E., Rangin, C., Imren, C., Armijo, R., Görür, N., Cagatay, N., Mercier, de Lepinay, B., Meyer, B., Saatcilar, R., and Tok, B.: The active Main Marmara Fault, Earth Planet. Sc. Lett., 192, 595-616, 2001.

Gladwin, M. T.: High-precision multicomponent borehole deformation monitoring, Rev. Sci. Instrum., 55, 2011-2016, 1984.

Gladwin, M. T. and Hart, R.: Design parameters for borehole strain instrumentation, PAGEOPH, 123, 59-80, 1985.

McClusky, S., Balassanian, S., Barka, A., Demir, C., Ergintav, S., Georgiev, I., Gurkan, O., Hamburger, M., Hurst, K., Kahle, H., Kastens, K., Kekelidze, G., King, R., Kotzev, V., Lenk, O., Mahmoud, S., Mishin, A., Nadariya, M., Ouzounis, A., Paradissis, D., Peter, Y., Prilepin, M., Reilinger, R., Sanli, I., Seeger, H., Tealeb, A., Toksöz, M. N., and Veis, G.: Global Positioning System constraints on plate kinematics and dynamics in the eastern Mediterranean and Caucasus, J. Geophys. Res., 105, 5695-5719, 2000.

Murru, M., Akinci, A., Falcone, G., Pucci, S., Console, R., and Parsons, $\mathrm{T}$ : $\mathrm{M} \geq 7$ earthquake rupture forecast and time-dependent probability for the sea of Marmara region, Turkey, J. Geophys. Res.-Sol. Ea., 121, 2679-2707, doi:10.1002/2015JB012595, 2016.
Parsons, T.: Recalculated probability of $M \geq 7$ earthquakes beneath the Sea of Marmara, J. Geophys. Res., 109, B05304, doi:10.1029/2003JB002667, 2004.

Prevedel, B., Bulut, F., Bohnhoff, M., Raub, C., Kartal, R. F., Alver, F., and Malin, P. E.: Downhole Geophysical Observatories: Best Installation Practices and a Case History from Turkey, Int. J. Earth Sci. (Geol. Rundsch.), 104, 1537-1547, doi:10.1007/s00531-015-1147-5, 2015.

Raub, C., Bohnhoff, M., Petrovic, B., Parolai, S., Malin, P. E., Yanik, K., Kartal, R. F., and Kiliç, T.: Seismic wave propagation in shallow layers at the GONAF-Tuzla site, Istanbul, Turkey, B. Seismol. Soc. Am., 106, 912-927, doi:10.1785/0120150216, 2016.

Reilinger, R., McClusky, S., Vernant, P., Lawrence, S., Ergintav, S., Cakmak, R., Ozener, H., Kadirov, F., Guliev, I., Stepanyan, R., Nadariya, M., Hahubia, G., Mahmoud, S., Sakr, K., ArRajehi, A., Paradissis, D., Al-Aydrus, A., Prilepin, M., Guseva, T., Evren, E., Dmitrotsa, A., Filikov, S. V., Gomez, F., Al-Ghazzi, R., and Karam, G.: GPS constraints on continental deformation in the Africa-Arabia-Eurasia continental collision zone and implications for the dynamics of plate interactions, J. Geophys. Res., 111, B05411, doi:10.1029/2005JB004051, 2006.

Sengör, A. M. C., Tuysuz, O., Imren, C., Sakinc, M., Eyidogan, H., Gorur, N., Le Pichon, X., and Rangin, C.: The North Anatolian Fault: a new look, Annu. Rev. Earth Pl. Sc., 33, 37-112, 2005.

Stein, R. S., Barka, A. A., and Dieterich, J. H.: Progressive failure on the North Anatolian fault since 1939 by earthquake stress triggering, Geophys. J. Int., 128, 594-604, 1997.

Tibi, R., Bock, G., Xia, Y., Baumbach, M., Grosser, H., Milkereit, C., Karakisa, S., Zünbül, S., Kind, R., and Zschau, J.: Rupture processes of the 1999 August 17 Izmit and November 12 Düzce (Turkey) earthquakes, Geophys. J. Int., 144, F1-F7, 2001.

Yalciner, A. C., Alpar, B., Altinok, Y., Özbay, I., and Imamura, F.: Tsunamis in the Sea of Marmara: Historical documents for the past, models for the future, Mar. Geol., 190, 445-463, 2002. 